DOI: $10.17516 / 1997-1370-0834$

УДК 81’373.612.2:578.834.1(510)(47+57)

\title{
Comparative Analysis of the Coronavirus Metaphorical Projections in the Chinese and Russian Mass Media
}

\author{
Oleg I. Kalinin ${ }^{\mathrm{a}, \mathrm{b}}$ and Alexander S. Romanov*a, \\ ${ }^{a}$ Military University, Ministry of Defense of the Russian Federation \\ Moscow, Russian Federation \\ ${ }^{b}$ Moscow State Linguistic University \\ Moscow, Russian Federation \\ 'Moscow State Institute of International Relations (University) \\ Russia's Ministry of Foreign Affairs \\ Moscow, Russian Federation
}

Received 29.08.2021, received in revised form 01.09.2021, accepted 14.09.2021

\begin{abstract}
This research focuses on a comparative analysis of the coronavirus metaphorical image in the Chinese and Russian mass media. The discursive theory of metaphor serves as a theoretical basis for our study. Within the framework of this theory metaphor is referred to as a cognitive frame, which operates in the discursive space for a certain period of time. J. Charteris-Black's Metaphor Critical Analysis has been used for the practical part of this paper. Linguistic analysis is based upon headlines and leads of Chinese and Russian news reports on the coronavirus pandemic. A total of 750 units of analysis in Chinese and 1,000 units of analysis in Russian have been examined. The authors arrive at the conclusion that media projections of the coronavirus image in the PRC and Russia are similar. Among the most widespread metaphorical models are «Virus is Enemy/Antagonist,» «Virus is Natural Disaster/Phenomenon,» «Virus is Living Creature,» and «Virus is Cause of Fear.» Despite overall homogeneity of metaphorical images, quantitative indicators of the distribution of metaphors and metaphorical implications (entailments) show significant differences. Critical analysis of Chinese and Russian media metaphors has made it possible to scrutinize public opinion within two different political systems.
\end{abstract}

Keywords: coronavirus, military metaphor, media discourse, metaphorical model, representation.

Research area: linguisctics.

Citation: Kalinin, O.I., Romanov, A.S. (2021). Comparative analysis of the coronavirus metaphorical projections in the chinese and russian mass media. J. Sib. Fed. Univ. Humanit. soc. sci., 14(10), 1499-1508. DOI: 10.17516/1997-1370-0834

(C) Siberian Federal University. All rights reserved

* Corresponding author E-mail address: biyalka@mail.ru 


\title{
Сопоставительный анализ метафорических проекций коронавируса \\ в медийных пространствах Китая и России
}

\author{
О.И. Калинина ${ }^{a, 6}$, A.C. Романов ${ }^{\mathrm{a}, \mathrm{B}}$ \\ ${ }^{a}$ Военный университет Министерства обороны РФ \\ Российская Федерачия, Москва \\ ${ }^{6}$ Московский государственныий лингвистический университет \\ Российская Федерачия, Москва \\ ${ }^{8}$ Московский государственный институт \\ международных отношений (университет) МИД РФ \\ Российская Федерачия, Москва
}

\begin{abstract}
Аннотация. Целью данной статьи ставится сопоставительный анализ метафорического образа коронавируса в китайских и российских СМИ. Теоретической базой исследования послужила дискурсивная теория метафоры. В рамках названной теории под метафорой понимается некий когнитивный фрейм, органично вписанный и функционирующий в данном дискурсивном пространстве на протяжении определенного времени. В основу практической части исследования положена методология критического анализа метафоры Дж. Чартерис-Блэка (Metaphor Critical Analysis). Материалом исследования послужили заголовки и аннотации (лиды) китайских и российских новостных сообщений, посвященных пандемии. Суммарно обследовано 750 единиц анализа на китайском языке и 1000 единиц анализа на русском языке. Делается вывод о том, что медийные проекции образа коронавирусной инфекции в исследуемой языковой паре схожи. К наиболее частотным репрезентациям отнесем следующие метафорические модели: «ВИРУС - это ВРАГ/ ПРОТИВНИК», «ВИРУС - эТо ПРИРОДНОЕ БЕДСТВИЕ/ЯВЛЕНИЕ», «ВИРУС - эТО ЖИВОЕ СУЩЕСТВО», «ВИРУС - эТо ПРИЧИНА СТРАХА». Несмотря на общую гомогенность метафорических образов, количественные показатели распределения метафор и метафорических импликаций свидетельствуют о значительных различиях. Критический анализ метафоры китайских и российских СМИ позволил сложить представление о моделях общественного мнения в рамках двух отличных политических систем.
\end{abstract}

Ключевые слова: коронавирус, метафора войны, медиадискурс, метафорическая модель, репрезентация.

Научная специальность: 10.02.00 - языкознание.

\section{Introduction}

The coronavirus infection outbreak has every reason to be considered one of the most significant global challenges of the year 2020 . According to expert estimates, the infection was first registered in Wuhan, the capital of China's Hubei Province. In a matter of months, the epidemic spread worldwide, claiming hundreds of thousands of human lives. The pandemic is by no means narrowed to the field of health care alone. COVID-19 intoxicated international relations, «infected» the world economy, brought down stock markets and had a destructive impact on all areas of society. The pandemic crisis involves legal, political, financial, economic, ethical, and other aspects.

COVID-19 sparked a crisis of confidence in authority. Harvard University Professor D. Jo- 
selit (Joselit, 2020) concludes that the spread of the new coronovirus in the United States and around the globe was made possible through «media of mass disinformation». The scholar argues that the real purpose of the media has nothing to do with informing the population. Instead, broadcasting fuels hysteria and fear. Unlike biological viruses infecting human cells, news agencies (governmental, public or private) seek to control viral forms of information. This is possible because, like any organic virus traveling from one host to another, the infovirus can no longer be curbed by any state measure. Opposed to social distancing, vacuum of information is almost unattainable.

There is little wonder the coronacrisis became a breeding ground for a number of conspiracy theories. The latter, in particular, question the effectiveness of mass vaccination against the background of the constantly mutating virus. Medical research reliability and preventive measures effectiveness face strong doubts. There exist numerous hypotheses that small and medium-sized businesses fell prey to key market players, namely transnational corporations, Internet giants, and pharmaceutical companies.

Every single social turmoil finds its reflection in the mirror of language. Mundane lexicon has been growing more and more medical. It registers a plethora of medical nominative units, namely social distancing, strain, virus mortality rate, lockdown, PCR testing, respiratory disease, airborne contamination, and a variety of others. The very perception of the term «pandemic» in layman's collective consciousness is changed. According to the Great Medical Encyclopedia, a pandemic (from Greek $\pi \tilde{\alpha} v$ (pan) - «all» and $\delta \tilde{\eta} \mu \mathrm{s}($ demos $)$ - «local people,» «the crowd») is referred to as the highest degree of epidemic development. A pandemic is an extremely severe epidemic spreading across countries and continents. Humanity is familiar with deadly epidemics of plague, cholera, influenza, and smallpox. In the 20th century the «Spanish Plague» (1918-1920) killed 20 million people in Europe, Russia, America, China, and India. Among the important criteria of pandemics are the index of contagiousness, mode of transmission, incubation period, lev- el of tension of collective immunity, and high mortality rate (GME, Vol. 18, Burgasov).

The virus devilry hides in its effects both on the body and mind. Under conditions of permanent information noise around COVID-19, the acuity of critical thinking is blunted. This happens because cognitive sphere suffers tremendous stress. Senses of anxiety and fear artificially induced in the target audience over a long period of time leave unhealed mental scars. Today words and viruses bear strong resemblance. Probably, the influenza virus was once a healthy lung cell. Later, that cell evolved into a parasitic organism that destroys the lungs. The same logic is applicable to verbal entities generated by the power of human thought. Probably, a word was produced by a healthy neural cell. Invading a healthy body, the verbal parasite affects the central nervous system (Burroughs, 1967).

Prescriptions of health care workers and recommendations of the authorities may protect you from an invisible and deadly disease. Nevertheless, protecting one's consciousness from information about the virus is out-of-thereach. There is no denying the fact that mass media is the main information channel about the virus and its consequences. Broadcasting discourse creates the epidemic image in the mind of the population.

The development of cognitive science and methods of critical discourse analysis allowed to expand purely linguistic research to the medical field (Wodak, Meyer, 2001). J. Reisfield and J. Wilson (Reisfield, Wilson, 2004) argue that militarized metaphors of cancer patients, emphasizing their heroic status, have a beneficial effect on the mental state.

Fear, however, is not always a bad thing. Fear can be channelized to trigger internal resources. O. Kalinin's study (Kalinin, 2020) concludes that metaphorical projection in the media is a powerful means to combat COVID-19. China is a fine example of successful countering the global menace. This is largely due to the fact that «the coronavirus representation in mass media was part of the state measures to combat the epidemic» (Ibid.). Chinese media well-balanced and consistent policies helped greatly prevent panic among the population. 
The scourge was portrayed as dangerous, but incapable of causing catastrophic consequences (Ibid.). Knitting the Chinese people together in the face of a killer virus, destructive and ubiquitous, was intended to do just that. Vivid metaphorical images of the national mass media became part of the state agenda. Metaphorical projections of «the PRC as a battlefield,» «medical workers' heroic confrontation,» and «the nationwide war on the natural disaster» are among striking examples.

The Russian Federation delivered less successful fight against the coronavirus. Faced with the disease in late spring 2020, Russia's government took a number of measures to stop COVID-19. Due to preventive measures the widespread invasion of the country was averted. National mass media played an important role in countering the pandemic. However, one has to admit that efforts of news outlets alone were not enough to mobilize the Russian people at the decisive moment.

\section{Purpose and hypothesis of the study}

The main purpose of this paper is to compare COVID-19 metaphorical projections in the Chinese and Russian media. This study explores a correlation between metaphorical images of the pandemic and extra-linguistic factors.

In line with our premise, the coronavirus metaphorical image in mass media is caused by (a) country's epidemiological situation, and (b) domestic political situation specifics. In this regard we put forward a hypothesis to be empirically tested. The media virus representation is an explicated discursive metaphor with the source domain of WAR. The content of the military metaphor is conditioned extralinguistically, namely by the virus spread dynamics inside the country and its internal political environment.

To maintain our hypothesis empirically, a total of 750 headlines and leads of news reports in Chinese were brought for analysis. We studied 15 news items daily for 50 days from January 21 to March 10, 2020. The period specified was marked by the deadliest attack of COVID-19 on China. Illustrative material in Russian comprises 945 news reports from
April 12 to June 14, 2020. Our analysis relies upon a random sampling method. 15 news reports on countering the coronavirus infection were studied daily. As opposed to Chinese, a longer time interval was chosen for the Russian language. Given the virus had targeted Russia later, stabilization of the situation was also delayed in time.

To reach the goal of this study, we have consistently solved a number of tasks as follows:

- A content analysis of headlines and leads in Chinese and Russian has been conducted;

- Most frequent COVID-19 metaphorical models have been revealed;

- The metaphor of WAR and its entailments in Chinese and Russian media discourses have been studied;

- A comparative analysis of results obtained in Chinese and Russian mass media discourses has been set forth.

\section{Theoretical foundations of the study}

M. Foucault (Foucault, 2002) defines discourse as a space permeated by a common idea and given in a system of concepts. This cognitive field brings together various texts on a certain subject. Understanding a particular discourse is impossible unless a set of extralinguistic factors of a particular chronotope is taken into consideration. This vital for our study idea merits special attention. Foucault argues that in relation to external factors, a language user personality plays a secondary role. Among an array of extra-linguistic factors are ideology, political conjuncture, social hierarchy of a particular society, etc.

The theoretical basis of this study comprises the Conceptual Metaphor Theory (CMT) (Lakoff, Johnson, 1980; Kövecses, 2016) and discourse theory of metaphor (Hülsse, 2003; Walter, Helmig, 2005). In addition, we have referred to works on Critical Discourse Analysis (CDA) (Weiss, Wodak, 2003; Wodak, Meyer, 2009; Simpson, Mayr, Statham, 2018a) and the Critical Metaphor Analysis (CMA) (CharterisBlack, 2004; Simpson, Mayr, Statham, 2018b).

CDA aims to identify and interpret metaphorical discourse patterns with respect to extra-linguistic factors. It is intended to exam- 
ine the impact of metaphorical models on the target audience collective consciousness.

Theoretical and methodological foundations of Critical Metaphor Analysis have been developed by J. Charteris-Black (CharterisBlack, 2004). This method is applicable to different languages and allows revealing implicit information of discursive metaphorical models. CMA has both purely theoretical and applied aspects (Li, 2016; Simpson, Mayr, Statham, 2018b).

German linguists J. Walter, J. Helmig and R. Hülsse (Hülsse, 2003a; Hülsse, 2003b) have pioneered the idea that metaphor is not only a cognitive phenomenon, but also a social one. Categorization structures expressed implicitly in metaphor contribute to shaping social reality. Discursive metaphor is understood as a relatively stable metaphorical frame for a given type of discourse. A discursive metaphor exhibits a number of attributes, namely length, stability, frame character and belonging to a certain discourse (Zinken, Hellsten, Nerlich, 2008).

A metaphoric implication (entailment) is referred to as extra shades of meaning mapped from the source domain to the target domain. Additional accents of a conceptual metaphor go beyond its basic meaning (Kövecses, 2005).

In this study metaphor is defined as a cognitive and discursive phenomenon. Moreover, mass media metaphorical projections possess a powerful manipulative potential. Metaphors of the conceptual domain of WAR shape the image of the enemy. A locutionary target mindset is effected by persuasion and suggestion. V. Chernyavskaya (Chernyavskaya, 2006) argues that persuasion appeals to rational thinking and urges to commit or refuse to commit certain actions. Suggestion, in its turn, appeals to emotional sphere and can be characterized as a hidden psychological influence. Informationideological confrontation implies (a) modeling and dehumanization of the external enemy's image; (b) persistent information support for the influence agent's positive image; (c) conquering and establishing hegemony over the enemy's information space (Romanov, 2020a).

COVID-19 information transmitted through mass media correlates with cognitive structures of the target audience's consciousness, acquires new conceptual features, and subject to categorization. In our opinion, a significant role in the virus media representation is attributed to metaphors.

When the author of an oral or written message (article or news report) transfers virus features (source domain) to other areas of human knowledge (target domain), he undoubtedly appeals to fundamental cognitive structures of his readers and exerts a powerful impact on the image creation. Here, we face two questions. What is the power of metaphor? And why does a stereotyped news report of factual details lose its persuasiveness?

In contrast to speech clichés and dry figure of statistics, metaphor shows vividness of the image. News stories repeated day after day lack creativity. The news media discourse subjects to the publicist style imperative, and therefore stereotypical. A stereotype is a simplified, rigid to new information, culturally determined and emotionally marked idea of a certain fragment of reality (subject, phenomenon or process), living both in individual and collective minds of entire social groups (Romanov, 2020a). Against the background of a faceless text, picturesque metaphorical images are intended to awaken the reader. Culturally determined stereotypes are embodied both in mental images-perceptions and verbal forms of these images (Romanov, 2020b).

Immersed in a standard news frame metaphor is an eye-catcher if its image is non-trivial. So called «dead metaphorical projections» with an erased inner form cannot do that. The opposite is true as well. Short of a stereotypical media message filled with statistics and clichéd formulas of journalism, metaphor loses its gloss. A focus on fundamental and universal social values (well-being, security, health or stability) and strong emotions multiplies metaphorical effect.

\section{Results of the study}

The analysis of 750 news reports in Chinese and 945 news articles in Russian reveals four most typical metaphorical models for the new coronavirus conceptualization: «Virus - is Enemy/Antagonist,» «Virus - is Living Crea- 
ture,» « Virus - is Natural Disaster,» and «Virus - is Cause of Stress». A total number of media discourse metaphors in Chinese is 611 and 504 for Russia's media.

First of all, we conclude that the Russian language shows lower level of metaphorization. On average, in Chinese there are 0.814 metaphors per news report, while in Russian the index is merely 0.53 . Figure 1 presents quantitative and percentage distribution of metaphorical models classified by source domain.

The percentage of identified metaphorical models for Chinese and Russian media discourses is set forth in Figure 2.

The composition of Chinese and English metaphorical models and the quantitative distribution of these models are quite similar. The distribution of WAR and FEAR metaphors displays obvious differences implicitly related to the sociocultural context. Let us consider the similarities and differences in more detail.
War metaphors are often used to describe various epidemics, pandemics, and diseases: cancer (Camus, 2009), AIDS (Sandahl, 2001), swine flu (Larson, Nerlich, Wallis, 2005), Ebola (Trčková, 2015), atypical pneumonia (Washer, 2004), and others. Using military terms, the fight against the plague in Manchuria is described in R. Kipling's "March of Spies» (Bogolyubov, 2020). War metaphors are widely used because in times of pandemic people seek to fight it and war is known to be the ultimate form of confrontation.

In case of China the metaphorical model with the source domain of WAR is the most frequent. This model accounts for $60.7 \%$ of all metaphorical representations. Metaphors are verbalized through such military terms as 抗 击kàngjī «to counterattack, to fight back»; 动 员 dòngyuán «to mobilize»; 消灭xiāomiè «to destroy, eliminate»; 杀灭shāmiè «to destroy, exterminate»; 预防 yùfáng «to prevent»; 打击 dăji «to strike»; 打赢 dăyíng «to win,» and others. It

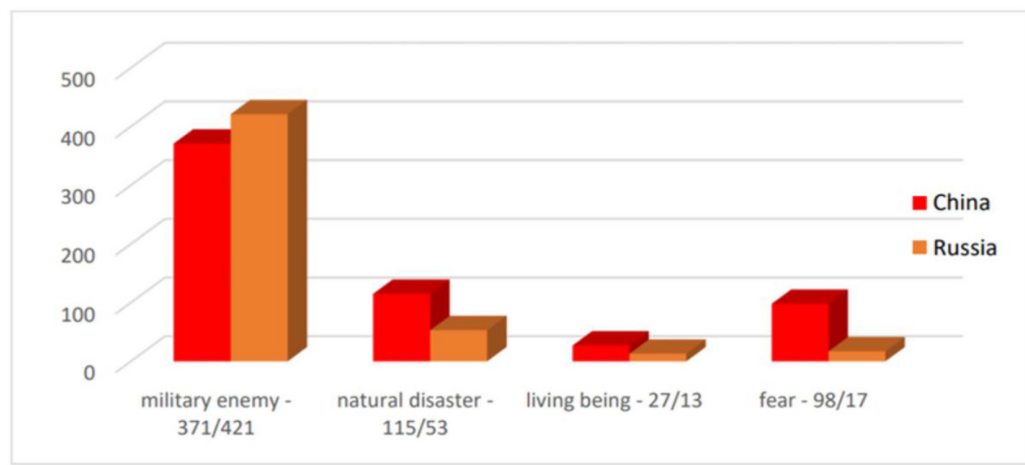

Fig. 1. Virus metaphorical models frequency in the Chinese and Russian online media discourses

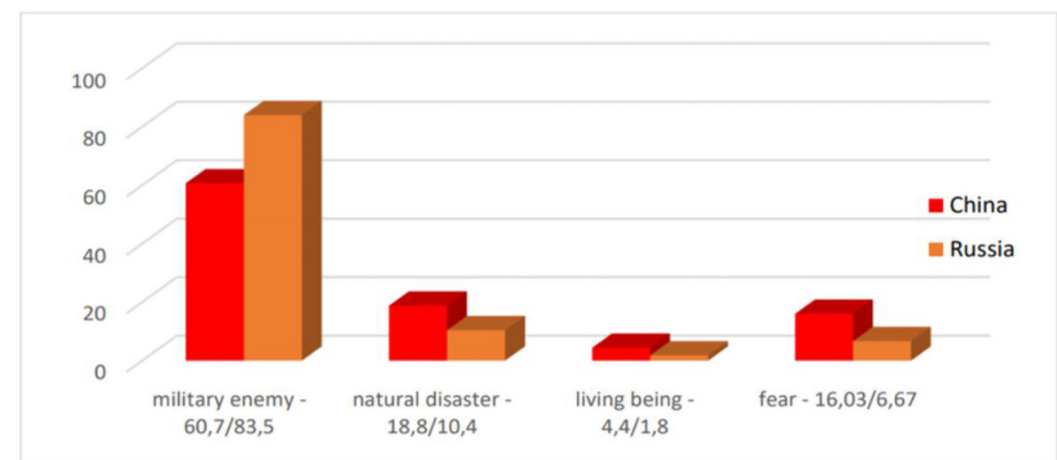

Fig. 2. Virus metaphorical models percentage ratio in the Chinese and Russian online media discourses 
should be noted that the term 打赢 dăyíng «defeat» began to prevail in news articles headlines from the middle of February. This period marks significant improvement of the epidemiological situation. Here, the neologism 战疫 zhànyì «war on the epidemic» (frequency rate - 27) is remarkable within this context.

«Fighting Virus is War» metaphor delivers six entailments. Their quantitative and percentage distribution is presented in Table 1.

Most war metaphors relate either to offensive or defensive hostilities. In quantitative terms metaphors of defense and attack are almost identical. The model «Medical Workers are War Heroes» is quite frequent, as opposed to the «Patients are Victims of War» metaphorical projection.

In Russian media discourse the metaphorical model with the source domain of WAR is even more popular. This model encounters 421 times out of 504 metaphors, which is $83.5 \%$. Leads and headlines use such military terms as «war,» «victory,» «enemy,» «attack,» «mobilization,» «strikes,» «to die,» «hero,» «frontline,» «battlefield,» «battle,» «attack,» and «fighting headquarters».
For Russia's media WAR terms are an obvious choice. Quite often military metaphors make part of news reports headlines. For example, «Medics are more important than generals in war,» «The market withstood the coronavirus attack». In most cases, the coronavirus is portrayed as an offensive enemy the Russian nation has to defend against. Allusions to reports from the Great Patriotic War front lines are not uncommon: «A 96-year-old veteran of the Great Patriotic War managed to defeat the coronavirus».

WAR metaphor entailments which describe fighting against the coronavirus in Russia are presented in Table 2.

The distribution of WAR metaphors entailments in Russia shows a little different picture. Slightly less than half of the metaphors relate to defensive activities against the enemy $(45.3 \%)$. There are much less metaphors of attack. This suggests that the virus is perceived as a suddenly attacked enemy. Medical heroes and victims of war on the virus metaphors demonstrate a fairly high percentage.

The Chinese media discourse makes use of a large number of metaphors belonging to

Table 1. The WAR metaphor entailments in the Chinese online media discourse

\begin{tabular}{lcc}
\hline \multicolumn{1}{c}{ Entailmnet } & Number & Proportion (\%) \\
\hline Fighting the virus is protecting against the enemy & 117 & 31,53 \\
Fighting the virus is attacking the enemy & 105 & 28,30 \\
Medical workers are war heroes & 72 & 19,41 \\
The fight against the virus is a common war & 29 & 7,82 \\
China is a battlefield & 32 & 8,62 \\
Patients are victims of war & 5 & 4,31 \\
\hline
\end{tabular}

Table 2. The WAR metaphor entailments in the Russian online media discourse

\begin{tabular}{lcc}
\hline \multicolumn{1}{c}{ Entailmnet } & Number & Proportion (\%) \\
\hline Fighting the virus is protecting against the enemy & 168 & 45,28 \\
Fighting the virus is attacking the enemy & 53 & 14,28 \\
Medical workers are war heroes & 107 & 28,84 \\
The fight against the virus is a common war & 15 & 4,04 \\
Russia is a battlefield & 9 & 2,42 \\
Patients are victims of war & 69 & 18,59 \\
\hline
\end{tabular}


the model «Virus is Natural Death». This figure is equal to $18 \%$ of the total number of identified metaphors. In this case the virus is perceived as a kind of dangerous element or physical agent. Sometimes this metaphorical projection is associated with a hurricane (frequency rate -3 ) or an earthquake (frequency rate -4$)$. Among the most widespread lexemes are 天灾 tiānzāi «natural disaster, irresistible force»; 灾害zāihài «disaster, misfortune»; 灾难 zāinàn «disaster, calamity».

In the Russian media discourse this metaphorical model accounts for nearly $10 \%$ of all metaphors. Disaster metaphors offer no national specific features. Most often these metaphorical projections are associated with the lexeme «disaster». For example, «no one discerned in the fog of things to come such a disaster as the coronavirus pandemic,» «the coronavirus epidemic hit the tourist market like a natural disaster».

The metaphorical projection «Virus is Cause of Fear» merits special attention. In this case, the basis for metaphorical mapping is fear though its source is not specified. In the Chinese media discourse such metaphors account for $16 \%$ of all metaphorical models. The frequency rate is 98 . For example, 担 忧之时 «in times of anxiety,» 是人类最害怕最讨厌的病毒 之一 «one of the most frightening and appalling viruses».

This metaphorical model plays a minor role in Russia's media discourse. We have identified only 17 such metaphors focused on lexemes «fear,» «anxiety,» «terrible dream,» and «terror.»

The least frequent metaphorical model for both discourses is the metaphor «Virus is Living Being». In Chinese the number of such metaphors is 27 as compared to 13 in Russian. The percentage distribution is $4.4 \%$ and $2.57 \%$, respectively. This group comprises all metaphorical models, associated with mechanisms of personification and comparison with humans or animals, real or mythological. For example, 疫情肆虐 - «the epidemic is rampant», 病毒虽然凶猛 - «although the virus is ferocious». The comprehension of viral infection as a living being largely reflects the mythological perception of nature, which is characteristic of
Chinese culture. Russia's media discourse features similar trends. Such metaphorical projections as "coronavirus coughs on the economy,» «coronavirus delivers a death sentence,» and «the rage of the coronavirus» clearly personify the plague.

\section{Discussion}

The image of the coronavirus in China's media is created through metaphors of war, natural disaster, and fear. The virus becomes an enemy, and the fight against it turns into hostilities. At the same time, the pandemic is a natural enemy sowing fear and anxiety. However, prevailing military metaphors contribute to figurative representation of the virus as a foe to be confronted and ultimately defeated. The collective conscience is instilled with the idea that the enemy is not so dangerous or fatally lethal, and probably will bring no serious consequences. Combating the plague, however, requires mobilization of the entire nation, which reflects Chinese traditional model of «meeting external challenges». Thus, the fight against COVID-19 implies active and coordinated actions both at the governmental and national levels. Under the media agenda, joint efforts should «strike» and «defeat» the virus.

The virus image representation in Russia's media is based on similar metaphorical models. The difference can be traced in the quantitative distribution of metaphors and their entailments. Russian mass media create an image of an unexpected adversary on the offensive, which is quite dangerous and claims multiple deaths. Much attention is paid to «viral attacks» on the economy, health care system, and international relations. Fighting the epidemic is portrayed as a «defensive war». The war consists in taking all necessary measures, however the question of how to win this confrontation has yet to be answered.

The use of the WAR metaphor differs in media discourses of the two countries. China sets forth a clear strategy. Defense comes first, followed by offensive leading to ultimate victory. The «war on the virus» is seen as a people's war with its own heroes. To avert panic among the population and prevent interfering 
with the conduct of the war itself, the Chinese media deliberately do not report on war casualties.

Russia's media demonstrate a more vibrant militaristic tone of speech. Nevertheless, modeling of the enemy image implies no offensive operations on the virus. News reports resemble more a list of recommendations rather than a piercing call for action. It's noteworthy that a significant number of references to victims and low-profile representation of the "Country is Battlefield» model has resulted in negative consequences. Having realized the problem, the nation has underestimated its magnitude and ignored urges for national mobilization. The Russian media have failed to create an image of the virus as a foe to be defeated. Instead, national media have created the «attacking enemy» image. As a result, attempts for general mobilization have been implemented only partially.

Within the framework of two different cultural and political systems we deal with two models of shaping public opinion on countering threats to social prosperity. The Chinese political authorities possess necessary resources to conduct general mobilization, quickly form public opinion, and prevent panic mindset among the population. There should be emphasized that the PRC has successfully coordinated governmental anti-virus measures with the strategy of the media covering. Shaping the vi- rus image has become one of the aspects of the anti-pandemic campaign.

Russia's media have also chosen to describe the epidemic in military terms. This corresponds to the national character, accustomed to unity in the face of the enemy. Due to the lack of a coordinated information agenda, the enemy image is incomplete and the Russian nation is still reluctant to wage a «people's war» against the plague. In contrast to China, Russia's authorities and its mass media have failed to present a united front.

\section{Conclusion}

The study of the coronavirus representation in the Chinese and Russian media has made it possible to juxtapose metaphorical models of the two countries. Among the reasons for differences identified are the domestic political situation and fundamental cultural differences. Extra-linguistic factors, such as the sick and recovered statistics are of great significance as well. Thus, the public opinion formation on the new virus in China has developed in parallel with measures taken by the authorities to combat COVID-19, which is not the case with Russia.

The results of our study confirm the role of metaphor in reflecting reality, as well as in shaping collective views of it. Metaphorical projections within media discourse have a significant impact on the public opinion.

\section{References}

Bogolyubov, A.F. (2020) Bring us Deliverance, Spy! (Interpretations of Kipling's The Spies' March in conditions of information war and pandemia). In Herald of the NSU. Series: Linguistics and Intercultural Communication, 2, 132-153.

Burroughs, W.S. (1967). The Ticket that Exploded. New York: Grove Press, 49.

Camus, J. (2009). Metaphors of Cancer in Scientific Popularization Articles in the British Press. In Discourse Stud, 11, 4, 465-495.

Charteris-Black, J. (2004). Corpus Approaches to Critical Metaphor Analysis. Hampshire: Palgrave Macmillan Book Company, 263. Available at:

Corpus Approaches to Critical Metaphor Analysis | SpringerLink.

Chernyavskaya, V.E. (2006). Discourse of Power and Power of Discourse: the problem of speech impact. Moscow: Flint; Nauka, 25-26.

Foucault, M. (2002). The Archaeology of Knowledge. Trans. by A. M. Sheridan Smith. London and New York.: Routledge, 30-35.

Great Medical Encyclopedia (GME). Pandemia / Burgasov A. P. ed. by Petrovsky, B.V., 3rd edition. V. 18. Available at: https://бмэ.орг/index.php/ПАНДЕМИЯ/. 
Hülsse, R. (2003). Sprache ist mehr als Argumentation. Zur wirklichkeitskonstituierenden Rolle von Metaphern. In Zeitschrift für Int. Beziehungen, 10, 2.

Joselit, D. (2020). Virus as a Metaphor. In October Magazine, Ltd. and Massachusetts Institute of Technology, 159-160. Available at: https:/direct.mit.edu/octo/article/doi/10.1162/octo_a_00400/96000/ Virus-as-Metaphor.

Kalinin, O.I. (2020a). Discussive Metaphora of Coronavirus in the PRC media. In Vestnik of the Moscow State Linguistic University. Humanities, 8 (837), 26-37. Available at: https://www.elibrary.ru/item. asp?id $=44325864$.

Kalinin, O.I. (2020b) Virus Image in the Chinese Media: Comparative Analysis of Coronavirus and Ebola Metaphoric Representation. In Topical Issues of Linguistics and Teaching Methods in Business and Professional Communication. Moscow: European Proceedings of Social and Behavioural Sciences. In Print.

Kövecses, Z. (2005). Metaphor in Culture: Universality and Variation. Cambridge: Cambridge University Press, 2005.

Kövecses, Z. (2016). Conceptual metaphor theory. In Routledge Handb. Metaphor Lang., 13-27.

Lakoff, G., Johnson, M. (1980) Metaphors we live by. Chicago: The University of Chicago Press., 242.

Larson, B., Nerlich, B., Wallis, P. (2005). Metaphors and Biorisks: the War on Infectious Diseases and Invasive species. In Sci. Commun. 26, 3, 243-268.

Li, W. Rethinking (2016). Critical Metaphor Analysis. In Int. J. English Linguist, 6, $2,92$.

Reisfield, G.M., Wilson, G.R. (2004). Use of Metaphor in the Discourse on Cancer. In Journal of Clinical Oncology. Available at: https://pubmed.ncbi.nlm.nih.gov/15459229.

Romanov, A.S. (2020a). Subcultural Constants Stereotypization in the Social-Group Dialect Axiology (as exemplified by values and realities of the military service in the U.S. linguistic culture): Dissertation for Postdoctoral Degree in Linguistics. Speciality: 10.02.19 - Theory of Language. M.: Military University, $113 ; 234-235$.

Romanov, A.S. (2020b). Subcultural Constants Stereotypization in the Social-Group Dialect Axiology (as exemplified by values and realities of the military service in the U.S. linguistic culture): Abstract of Dissertation for Postdoctoral Degree in Linguistics. M.: Military University, 22.

Sandahl, C. (2001). Performing metaphors: AIDS, disability, and technology. In Contemp. Theatr. Rev. Perform. Disabil. Spec. Issue. 11, 49-60.

Simpson, P., Mayr A., Statham, S. (2018a). Critical Linguistics and Critical Discourse Analysis. In Language and Power. Second edition. Milton Park, Abingdon, Oxon; New York,: Routledge, 58-65.

Simpson, P., Mayr, A., Statham, S. (2018b). Critical Metaphor Analysis. In Language and Power. Second edition. | Milton Park, Abingdon, Oxon; New York,: Routledge, 229-236.

Sun, Y et al. (2021). The use of metaphorical indices to analyze the speech impact of metaphor in the texts of public speeches of politicians / Y. Sun, O.I. Kalinin, A. V. Ignatenko. In Russian Journal of Linguistics. 25, 250-277.

Trčková, D. (2015). Representations of Ebola and its victims in liberal American newspapers. In Top. Linguist. 16, 1, 29-41.

Walter, J., Helmig, J. (2005). Metaphors as Agents of Signification. Towards a Discursive Analyses of metaphors. In ECPR Granada Workshop Metaphors in Political Science.

Washer, P (2004). Representations of SARS in the British Newspapers. In Soc. Sci. Med. 59, 12, $2561-$ 2571.

Weiss, G., Wodak, R. (2003). Critical Discourse Analysis: Theory and Interdisciplinarity. Basingstoke: Palgrave Macmillan, 2003.

Wodak, R., Meyer, M. (2001). Methods of Critical Discourse Analysis / ed. by R. Wodak, Michael Meyer. 6 Bonhill Street, London EC2A 4PU: SAGE Publications. Available at: https://www.academia. edu/1614495/Methods_of_critical_discourse_analysis.

Wodak, R., Meyer, M. (2009). Methods of critical discourse analysis. 2nd ed. London: Sage.

Zinken, J., Hellsten I., Nerlich, B. (2008). Discourse metaphors. In Discourse, 1-25. 